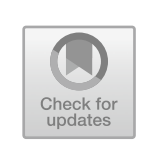

\title{
Buddha on Politics, Economics, and Statecraft
}

\begin{abstract}
This chapter outlines doctrinal Buddhist political and economic theory including its notions about interstate relations, which are based on its unique understanding of the nature of reality. Some readers may be surprised to hear that there exists a theory of politics in Buddha's teachings. But in fact, Buddha spoke extensively about politics, contrary to the assertion of Max Weber who famously asserted that Buddhism was "a specifically a-political and anti-political status religion." Although the overriding goal of Buddha's teachings is the liberation of individuals from pervasive suffering, Buddha considered politics as important, not so much for its intrinsic value, but because it created an external environment that can facilitate or impede an individual's pursuit of happiness, defined as spiritual advancement and achievement of wisdom about the true nature of oneself and the world. Although best understood as an extension of his teachings on human liberation, Buddha was also an original social and a significant political philosopher. Buddha's social teachings parallel modern democratic thought, mixed market economics, and cosmopolitan internationalism in the West. This chapter outlines Buddha's political and economic theory, including his thoughts about statecraft and the possibilities for international order.
\end{abstract}

Keywords Buddhist politics - Buddhist economics - Buddhist statecraft 


\section{Buddha ON Politics ${ }^{\mathrm{I}}$}

Early Buddhist literature ${ }^{2}$ addresses several political, economic, and international issues. While the primary purpose of Buddha's teachings is the liberation of individuals from pervasive suffering, his teachings also acknowledge the interdependence of the individual with society, polity, and economy. Buddha's teachings sought to mediate these relationships constructively. Although largely unknown in the West, Buddha was an original and important social, political, and economic philosopher, and a rationalistic, humanistic, and democratic one at that (Ling 1981).

What are the essential elements of Buddha's normative vision for politics? Buddha saw politics not as an end in itself but as an instrument that could either provide favorable conditions or create harmful obstructions for individuals' personal advancement. Buddha recognized that government is necessary to provide social order and welfare and that its values, content, and processes should be consistent with the "dharma." "Dharma" (dhamma in Pāli) has many meanings but here refers to the teachings of Buddha and their realization, which are offered as universal or natural laws - such as the law of dependent arising and the suffering that results from ignorance of this basic truth. These laws are not created by Buddha, they operate with or without him, but Buddha revealed these laws and recommended that we examine them and act accordingly; not through blind faith, but through a process of rational human assessment. ${ }^{3}$ A political system organized consistent with these basic truths could minimize the manifest forms of suffering for all members of society-especially for the least fortunate whose visible suffering is greatest-and play a positive role in an individual's attainment of higher forms of well-being.

What does it mean to say that political practices must be consistent with the dharma for their legitimacy? A fundamental principle of the dharma relevant to politics is the equality and dignity of all individuals. Buddha stressed that all human beings have an inherent worth and capacity for enlightenment, so-called, "Buddha nature." 4 In contrast to the prevailing Brahmin teachings, Buddha rejected the caste system and argued that virtues were distributed equally, not hierarchically, across society. Buddha states: "Now since both dark and bright qualities, which are blamed and praised by the wise, are scattered indiscriminately among the four castes, the wise do not recognize the claim about the Brahmin caste being the highest ... [anyone can] become emancipated ... by virtue of dharma" (DN, 27, 2012 at p. 408). The dharma applies equally 
to everyone regardless of class, social status, or economic circumstance. Because citizen and ruler alike are equal under the law of dharma, political institutions should reflect this basic truth. For it's time these were truly groundbreaking social insights.

Buddha's teachings also reflect the principle of equality when he prescribes that monarchy, the dominant form of government during his lifetime, should be based on popular consent (not divine right), conducted in consultation with the governed, even-handed in the application of justice, and conform to the dharma. Democracy, however, is the form of government where equality is paramount, and Buddha's own political creation, the sangha (the order of monks and nuns in Pāli and Sanskrit), is governed by strict equality in its rules for admission, participation, administration, and dispute resolution.

Because of the equality and ultimate goodness of every individual (and because they all suffer), Buddha taught that they are each worthy of our compassion and, at a minimum, should not be harmed by the state. Nonviolence or non-harm (abimsa in Sanskrit and Pāli) is a natural corollary to Buddha's teachings on the equality of human potential and the basis of the protection of individual rights. ${ }^{5}$ Perhaps the most direct example of this principle to politics is Buddha's repeated admonition that a righteous ruler must follow the ethical precepts of no killing, no stealing, no lying, etc. More affirmatively, the successful leader must demonstrate compassion and care through the practices of kindness, equanimity, patience, and generosity. Nonviolence and equality are the bedrocks of Buddhist social justice, and good government requires moral and legal protection against the arbitrary use of power. Buddha, like America's founding fathers, was concerned about the danger of tyranny.

The third feature of Buddha's political teachings is a tolerance for different political configurations and a pragmatic and non-doctrinaire ("liberal" or "pluralistic" in this sense) approach to political questions. Rather than overtly endorsing a particular form of government, Buddha, in befriending and advising republics and monarchs alike, implies that good governance can take more than one form but must allow for the maximization of individual happiness of its citizens (defined in a way that goes beyond mere sensual enjoyment to include self-realization) and that minimizes their suffering, allowing them to cultivate compassion, patience, generosity, meditative concentration, and wisdom while discouraging greed, hatred, and ignorance. Buddha did not explicitly advocate for a single form of government, and, at one level, recognized that different 
types of regimes could be considered legitimate if the spirit of the ruler and the ruled was in accordance with the dharma.

Nonetheless, Buddha indicated a preference for democratic and representative forms of government. In his teachings and prescriptions, Buddha endorsed democratic principles such as citizen participation and free expression of opinion; deliberation, consultation, and consensus-building; voting and respect for popular consent; transparency via face-to-face meetings and public debate; primacy of the rule of law and limited government. We see these predilections in Buddha's endorsement of republican principles in the sütras and the incorporation of democratic principles into the rules governing Buddha's own society of monks and nuns in the vinaya. Buddha's teachings are directly relevant to contemporary politics and are compatible with the governance of a modern democratic state. Buddha's political thinking parallels Western liberaldemocratic thought with its emphasis on equal rights, protection against tyranny via equality before the law, and participatory and deliberative governance.

The most important distinction between "dharmic" democracy and Western liberal democracy is Buddhism's emphasis on one's individual duties to others as much as one's individual rights, duties that exceed compliance with the law. Where liberal democracy has little to say about the moral qualities of what constitutes good governance beyond the values of equality of opportunity and protection of individual choice and instead focuses on the process of good governance not the substance (Garfield 2001), "dharmic democracy" delineates a clear duty of care owed to others and to the natural world as well. Fundamentally, in dharmic democracy individuals have a duty not only to avoid abridging other's freedoms, but to strive to develop a sense of universal responsibility and concern for all human beings and the natural world. Although this duty is everyone's responsibility, political institutions and their leaders should reflect these principles, and policy should encourage their inculcation and practice. The emphasis on responsibilities as well as rights follows directly from Buddhism's underlying ontology of dependent origination and a theory of causation that maintains our lives are not separate but deeply interdependent. Contemporary Buddhist writer and monk, Thich Nhat Hanh, captured this difference in the context of the United States when he remarked: "We have the Statute of Liberty on the East Coast. I think we have to make a Statute of Responsibility on the West Coast to counterbalance Liberty. Liberty without responsibility is not real liberty" 
(Hanh 2006 at p. 137). "Freedom" in Buddhist thought means freedom from the chains of self-grasping ignorance, not the unbridled pursuit of "self" interest.

\section{BUDDHA ON ECONOMICS}

Just as Buddha had important things to say about politics, he offered numerous profound and practical insights on economic matters throughout the sütras. These teachings provide guidance on how spiritual advancement and material well-being could be compatible and mutually supportive.

The purpose of economic activity in Buddhism is to provide the necessary material basis for individuals to enjoy a comfortable life, thus freeing them to pursue higher forms of well-being. Production, consumption, and distribution of material goods should reduce suffering and provide sustainable welfare and dignified work for all members of society through the wise use of scarce resources. This view of economic activity as a means toward higher ends contrasts with classical or neoclassical Western economics where the focus is on material well-being alone and production, consumption, and distribution are designed to maximize an individual's "utility" or "welfare" through ever-increasing material production and consumption, in the aggregate, to grow Gross Domestic Product (GDP), under resource constraints.

Like politics, Buddhism treats economic life as part of living in accordance with the dharma and therefore views it as part of a larger ethical framework from which it cannot be separated. ${ }^{6}$ By virtue of the doctrine of radical interdependence, economic activity is necessarily part of a larger whole, an important part, but only a part, and it must be kept in harmony with familial, social, environmental, and spiritual aspects of life. In Buddhist economics, there are no "externalities." Economic progress, for oneself or society, is not an end in itself but part of broader process of personal and social advancement.

Nonetheless, Buddha warned against ignoring physical needs and eschewing material pursuits, and recommended balanced progress in material and spiritual well-being-a so-called "Middle Way" between physically destructive asceticism and soul-crushing material indulgence as the way to happiness. The goal of Buddhist economics is to provide material security and economic stability for individuals and society and 
sustainable growth. The state must guarantee the physical needs of individuals in the form of the "four essentials": food, clothing, shelter, and medicine, as these constitute the foundation for other pursuits such as moral development and the acquisition of wisdom.

Buddha's economic teachings are not anti-wealth. He taught that no suffering arises from experiencing or enjoying objects of the senses. The problem with material wealth arises from our pervasive delusion that misapprehends the real nature of phenomena in our samsaric existence as discussed in Chapter 2. That is, we forget the impermanent nature of material pleasures and are misled into thinking they are a true source of lasting happiness. It is our craving and grasping at evanescent objects (and ourselves) based on fear, greed, and the underlying ignorance of the nature of reality that leads to suffering. The problem lies neither with the objects of the senses nor the enjoyment derived from them, but from misperception of their impermanent nature and the pursuit of material objects as the supreme source of happiness for a self that also ultimately does not exist. Wealth, then, does not stand in the way of liberation, but the attachment to wealth does.

For laypeople, Buddha recommended the acquisition of wealth and material prosperity through industry, frugality, entrepreneurship, and resourcefulness, but he also advocated for values such as concern and care for others, non-harm, generosity, and, eventually, nonattachment to wealth given its impermanence and inability to provide lasting happiness. To be nonattached "is to possess and use material things but not be possessed or used by them" (Sizemore and Swearer 1993 at p. 1).

Consumption, like wealth, is not discouraged by Buddha, but one should remain mindful of its associated risks. ${ }^{7}$ Because humankind has virtually unlimited desires, Buddha encouraged moderation in consumption that can distinguish material needs and wants. ${ }^{8}$ As guidance in making this distinction between needs and wants, Buddha listed the following things money should be spent on: food, clothing, and shelter; attending to parents; treating relatives and guests; alms in memory of the departed; religious offerings; and payments to the state (AN, 3:45, 2012).

In short, for individuals, Buddha advised a balanced life, free from the sufferings of both poverty and indulgence and guided by wisdom, discernment, and right view. This approach can lead to a deeper sense of contentment, which Buddha said is "the highest form of wealth" (Dhp. 204, 2007). In Buddhism, it is one's attitudes and actions about wealth, not the level of wealth, that is important. Nonattachment is the 
appropriate attitude toward wealth, which can be cultivated by acquiring wealth through righteous means, consuming it with moderation, and developing contentment and sharing wealth generously, but wisely ( $\mathrm{SN}$, 99, 2000).

For the state, poverty is the primary threat to individual and societal advancement and providing sufficiency in the four material requisites for all is the first purpose of a political-economic system. Both the individual and the state have a duty to protect and promote the welfare of all citizens. For the individual, this duty of care for others flows from the development of higher states of mind such as generosity and compassion and an appreciation for the equality and dignity of all human beings. But charity alone will not fully address the problem. The challenge of poverty must be dealt with systematically, necessarily involving government policy that can fully utilize the productive resources of society (DN, 5,2012 ). If the state fails to care for its citizens it could lose its legitimacy and create social pathologies and unrest. The state must also prevent economic injustice, eliminate corruption, and protect the environment and consumers from exploitation. Thus, Buddha's teaching envisions a somewhat greater role for the state in economic affairs than in most traditional liberal economic models, but his prescription is not too different from the welfare liberalism found in many advanced market economies.

As for the private sector, Buddha acknowledges that possession of private property by the laity is a pragmatic response to our egocentric tendencies and an efficient means for creating incentives for work and productivity (DN, 27, 2012). ${ }^{9} \mathrm{He}$ recognized commerce and profitmaking as legitimate and necessary economic activities. Buddhist economics is in no way anti-business. The sütras encourage economic freedom and entrepreneurship if pursued righteously, without harm to others, and without excessive greed. At various points throughout the canon, Buddha encourages business people to be energetic, mindful, pure in deed, self-controlled, considerate, right living, and heedful. Indeed, the merchant classes were among the first proponents of Buddhist philosophy and carried Buddhism throughout Asia. Traders are advised to act with wisdom, acumen, and reliability and should know what is an appropriate profit margin for their goods (AN, 1:116, 2012). Profits are essential and necessary if they are obtained honestly and without fraud or cheating. Business people are encouraged to work hard and avoid laziness and managerial efficiency is praised. One writer described the tenor of Buddha's economic advice contained in the sütras as "unmistakably 
bourgeois" (Reynolds 1993 at p. 71), another as reflecting "merchant type" values (Ornatowski 1996 at p. 206). Profitmaking should not be the only concern of producers and traders, however, as they have responsibilities to their employees, ${ }^{10}$ society, and the natural world too. And trading in certain goods is explicitly prohibited, namely trade in weapons, living beings (slave trade), butchering, intoxicants, and poisons (AN, III: 209, 2012).

With regard to the relationship between economic activity and the environment, Buddha was one of the first thinkers to advocate for environmentally sustainable economics as an essential social principle. Because of our deep interdependence and our ethical responsibilities, which extend beyond humans to all sentient beings and the natural world in this and future lives, Buddha advised maintaining a proper relationship between productive activities and the environment. Buddha asserted that in amassing wealth humankind must treat nature as a bee collects pollen in that the bee harms neither the beauty of the flower nor its fragrance and ensures its future fruition. Analogously, economic production must not harm the natural environment or impair the well-being of future generations by destroying nature's regenerative powers or its beauty (Dhp. 2007 at p. 49). Buddhism does not view the environment as a divine creation for human exploitation, nor is it seen as "external" to the production process. It too must be treated with care and without harm as humans and nature are interdependent.

Buddhist economics differs from dominant Western models in several important dimensions and yet is not fundamentally estranged from Western thinking. At a fundamental level, the most important difference is that whereas liberal market economics view the material world as real and permanent and the source of happiness, in Buddhist economics material reality is seen as impermanent, and if treated wisely, as the source of lesser happiness and prerequisite to higher forms of well-being. Liberal economics is concerned with satisfying the ever-expanding needs and wants of the self, and Buddhist economics is a means to assist individuals in transcending the self and controlling the negative emotions underlying our untamed desires through the development of moderation, contentment, and wisdom (of the nature of reality). Buddha's approach emphasizes right view: understanding the true nature of our existence, and right livelihood, working, acquiring wealth, and consuming consistently with this view. With right view, one recognizes the ultimate impermanence and insubstantiality of ourselves and all phenomena and 
understands that material things are not the source of true happiness and that clinging to them will only perpetuate our suffering. Finally, from a Buddhist perspective, it follows that increasing output and consumption is not necessarily an accurate measure of improvements in the well-being of society or its members. Measuring societal well-being as synonymous with the expansion of GDP is flawed and must be replaced with more holistic metrics that consider a much broader range of factors important to human flourishing and that examine the quality and sustainability of growth. Many international organizations are moving in this direction, ${ }^{11}$ and in Chapter 5 we will see the application of these economic principles in Bhutan's Gross National Happiness (GNH) development policies.

Like Buddha's thoughts on politics, his economic teachings do not mandate a single economic system, but are broadly compatible with a modern, mixed market economy. By mixed market, I mean the belief that while markets do many things well, they are not the answer to all economic problems, and that the government has some responsibility to uphold in the economic sphere societal values that exceed liberty and legal competition to include a duty of care for others and the environment.

So, despite the differences between Buddhist and liberal economics, these approaches have much in common and a meaningful discussion is possible between the two philosophies regarding important contemporary economic issues such as poverty and income inequality, sustainability, business-government relations, and the role of the state among others (Daniels 2005). Importantly, both Buddhist economics and liberal market capitalism share a rational and pragmatic approach to economic issues that recognizes a role both for the public and private sector. Much like Buddha on politics, Buddhist economics is not doctrinaire and suggests that economic systems must be flexible and culturally appropriate for a particular time and place (Welford 2007). This adaptability also opens the door to a consideration of the possible contemporary relevance of Buddha's economic teachings to modern life.

\section{Buddha on International Relations and Statecraft}

The Buddhist conception of politics as serving the common good extends to the international realm where our humanity and fundamental interdependence ultimately transcend national, racial, and other barriers, which are, at most, only conventional distinctions. This is not to say that the state must wither away in Buddhism. States, like our conventional 
designation of our "selves" as distinctive individual entities, can function effectively as long as one recognizes their nominal, transactional, and dependent nature and avoids grasping at them as inherently real. States can serve an important function by equitably supplying public goods. Likewise, a system of such like-minded states can "exist" and function effectively, if one recognizes and does not lose sight of the deeper, interconnected nature of all things.

Thus, Buddhist statecraft is an international extension of Buddhist political and economic principles of equality, harmony, social welfare, nonviolence, conciliation, and mutually beneficial commercial exchange what has been summed up above as ruling in accord with the dharma, sometimes called "righteousness" in the Buddhist cannon. ${ }^{12}$ Buddha discusses statecraft mostly in parables, ${ }^{13}$ introducing the concept of world-ruler (cakkavatti in Pali, cakravartin in Sanskrit), who would provide exemplary leadership for states in the international system. The cakkavatti is a lesser or worldly Buddha that provides for the material welfare (more than the spiritual welfare) of mankind. ${ }^{14}$ By example and generosity (not violent conquest), this ruler (either a single individual or a representative body) establishes an ideal government with the consent of the governed which is followed by a series of similar democratic and constitutional states based on shared principles. This loose network of ideal states would constitute an international political system that served the interests of worldwide peace and prosperity. One can see certain parallels here with Kant's vision of perpetual peace among like-minded representative states and with democratic peace theory and notions of an "international society" and cosmopolitanism in modern Western IR writings.

Buddhist IR begins with the establishment of a righteous state, ruled by consent of the governed with policies consistent with the dharma. This government would work for the interest of its people with care, impartial justice, tolerance, and the equal promotion of material and spiritual welfare of society's members. In modern parlance, the exemplar would be an enlightened democratic welfare state guaranteeing freedom and economic security and promoting equality, tolerance, and care for its citizens (Jayatilleke 1967). In time, this model would extend naturally and infectiously or "travel" to other parts of the world, via the Buddhist metaphor of a rolling "Wheel of Dharma," much like Buddha's initial teaching after his enlightenment set in motion a wheel of spiritual guidance. These other countries, in turn, would establish similar states 
with analogous governing principles and constitutions. The international system would not be centralized empire, but a loose constellation of states revolving around an archetypal entity (Tambiah 1976).

In relating with other states, hostility and aggression is forbidden and the cultivation of friendliness and neighborliness and mutually beneficial commerce is endorsed, both to conform with the dharma and on grounds of expediency and efficacy, that is, aggression does not serve one's selfinterest in the long run. Buddha counseled, "Hatred never ceases by hatred in this world. Hatred ceases by love-this is the ancient law" (Dhp. 2007 at p. 105). ${ }^{15}$ A state could retain its army for defensive purposes but nonviolence is thought to be the higher ideal and Buddha counseled against the resort to war as a means of settling international disputes (King 2013). ${ }^{16}$ The first ethical principle in Buddhism is to refrain from killing or injuring any sentient being. There is little or no support for "just war" in Buddhism (Jerryson 2013; Jayasuriya 2009). Buddha said that wars only perpetuate future conflict. As noted, he also spoke out against the trading in weapons as "wrong livelihood."

In sum, in foreign affairs, the state has the obligation not to commit aggression and to cooperate with other states in a spirit of friendliness and equality for the common good of mankind. Like all Buddha's advice, this admonition was offered for its practical benefits-it strengthened both the individual state and encouraged common bond of humanity that would bear fruit in international peace and prosperity. Buddha's political doctrine of equality, democracy, popular sovereignty, and political institutions that serve the common good materially and spiritually find their ultimate fulfillment in a worldwide network of states each acting according to these principles. Hence, in Buddhism, states may exist, but they are artifacts that endure for the benefit of a broader humanity.

\section{EMPIRICAL REFERENTS FOR BUdDHist STATECRAFT: AśoKA's MAURYAN EMPIRE AND CONTEMPORARY BHUTAN}

Buddhism has shaped many cultures throughout Asia and, more recently, has become influential in the West. Buddhism's political impact has been more muted, however, in part, because from the start the Buddhist order, the democratic sangha, was to remain apart, although not wholly separate, from politics. ${ }^{17}$ The devoted practitioners of the sangha were to be considered a source of advice and example to the wider society and polity, but refrain from participating directly in the political process. So, 
there are few instances where one can find an empirical example of a political system founded truly on Buddhist principles or practicing what might be called Buddhist statecraft. This is not to say that Buddhism has not been used by politicians past and present to cloak their actions in Buddhist rhetoric, much as other religious traditions have been used, only that an authentic effort to align Buddhist principles with political practice is quite rare. I offer two possible cases of Buddhist statecraftone ancient and one modern (an alpha and omega)-for consideration. The ancient case is the Mauryan Empire of King Aśoka, the first ruler of a Buddhist state, and the modern case is contemporary Bhutan-the only extant example of a democratic state that is rooted constitutionally, politically, and economically in Buddhism. ${ }^{18}$

\section{Notes}

1. Portions of this discussion are taken from the author's earlier work, Tantric State: A Buddhist Approach to Democracy and Development in Bhutan, New York: Oxford University Press, 2019.

2. The discussion of Buddhist political and economic principles presented here is drawn from several well-known sütras that bear on political or social matters and from the vinaya. These sütras include the: Mahāparinibbāna, Aggañña, Mahāsudassana, Cakkavatti-Sīhanāda, and Kütadanta. For purposes of names, I use the Pāli language names as they appear in the translated canon.

3. God-given laws or commandments do not exist in Buddhism, only vows people take for their own well-being to assist them with their spiritual advancement. Vows are the acknowledgment of naturalistic facts about how the universe operates. In this sense, Buddhist ethical recommendations are often described as "conditional," "hypothetical," or "non-categorical," although these characterizations of Buddhist ethics are the subject of much debate (Moore 2016).

4. Buddhism, particularly the branch known as Mahayana Buddhism, maintains that humans and all other sentient beings possess Buddha nature. As noted, the concept "Buddha nature" is complex and the topic of inter-sectarian doctrinal dispute. For our purposes, the basic idea is that all individuals possess the essence of the Buddha's enlightenment, which forms the basis for all positive qualities. These qualities are not states of mind to be added; they are already fully present but obscured by grasping at an inherent self, dualism, and other misconceptions that flow from this misunderstanding of reality.

5. On Buddhism and human rights see Damien Keown (2000). 
6. Buddha's economic ideas are firmly rooted in his first teachings on the Four Noble Truths: the truth of suffering, the causes of suffering, the cessation of suffering, and the path that leads to cessation of suffering. The "path" is known as the Noble Eightfold Path and the fifth step of that path, "Right Livelihood," is the material dimension of the moral practice necessary to achieve enlightenment.

7. Because wealth often produces craving, attachment, jealousy, and other unhealthy minds, Buddha advises worldly people to develop four qualities that will protect them from developing negative attitudes toward wealth and its use, namely: (1) confidence in the law of karma; (2) morality or virtue; (3) generosity; and (4) discernment (as to the true nature of reality) (AN 4:284, 2012). Developing these qualities will inoculate one from the potential dangers associated with wealth.

8. Regarding our desires, Buddha remarked: "Even a shower of gold cannot quench the passions" (Dhp. 186, 2007).

9. In contrast, common property and a conscious decision to not engage in the material world is recommended only for those few who make a voluntary commitment to withdraw from productive economic activity to strive vigorously for nonattachment (although overcoming craving for wealth is a chief obstacle to enlightenment for both laity and the ordained). The monastic orientation toward wealth is not expected of, or recommended to, the laity. Indeed, the intense pursuit of spiritual advancement leading to the foregoing of productive economic activity and the virtual elimination of private property by the ordained would not be possible unless the laity followed a different economic model that included economic productivity, private property, and growth sufficient to create a surplus from economic activity that could sustain the materially nonproductive sangha.

10. The Sigalovada Suttra explains what constitutes appropriate employeremployee relations. An employer has five duties that must be fulfilled toward an employee: (1) assignment of work in accordance with the capability of the employee; (2) provision of food and wages; (3) provision of medical care (benefits); (4) sharing of windfalls (today what we might call offering bonuses or profit sharing); and (5) granting leave and vacation at the proper times. Employees, in turn, owe their employer the following: to (1) rise early; (2) go to bed late; (3) refrain from stealing; (4) discharge their duties well; and (5) speak well of their employer. Fulfilling these mutual responsibilities will lead to increased output and productivity (DN, $31,2012)$.

11. Emerging trends in scholarship and policy focus less on GDP and increasingly on alternative and expanded measurements of national progress such as the United Nation's Human Development Index and its Sustainability 
Goals, the Happy Planet Index, the Genuine Progress Indicator, the Organization for Cooperation and Development's Better Life Index, and others (Brown 2017).

12. U.N. Ghoshal called the "total application of the principle of righteousness" to politics "the most important contribution of the early Buddhists canonists to the store of our ancient political thought" (Ghoshal 1959 at p. 69).

13. Buddha, using skillful means, offers guidance on how to promote harmonious social relations through parables, rather than through direct recommendations to an actual monarch, as that would have been inappropriate, ineffective, and dangerous (Chakravarti 1987). Given the growth in monarchies during Buddha's lifetime and their aggressive ambitions and violent methods, compromise and accommodation with this form of government was unavoidable, and ameliorating extreme forms of royal despotism by instructive parables was an adroit method of indirectly advising kings and humanizing and constraining the worst excesses of monarchy. If Buddha did not prescribe a vision of international relations in greater detail, keep in mind this was not his primary task and one can look to his detailed directions in the vinaya, instructions for the sangha, for more specific guidance on political administration.

14. See the Cakkavattisibanada sütra D.N. 26 and Mahasudassana sütra D.N. 17 (2012).

15. The quotation continues, "Victory breeds hatred: the vanquished live in sorrow. The peaceful ones live in harmony giving up both victory and defeat. Conquer enmity with amity, evil with good, miserliness with charity, and falsehood with truth" (Dhp. 2007).

16. See Buddha's advice to the Sākya and Koliya tribes who stood on the threshold of war over contested water rights (Jayatillake 2008).

17. In Indian society during Buddha's lifetime and immediately afterward, the relationship was conceived as a triangle among the state, the sangha, and the laity. Society and government supported the sangha materially, and the sangha, in turn, legitimated and counseled the government and educated and modeled the dharma for the laity. This triangular relationship was adopted by other Buddhist Asian societies, such as Burma/Myanmar (Walton 2012).

18. Buddhist comprise about two-thirds to three quarters of the Bhutanese population and the constitution provides that the King is both head of state and protector of the Buddhist faith and culture. Buddhism is not explicitly the state religion, but it is strongly emphasized in Bhutan's constitution and institutions. For a comprehensive discussion of the Bhutanese political and economic system in theory and practice and its relationship to Buddhism see Lee (2014), Long (2019). 


\section{REFERENCES}

AN. 2012. Anguttara Nikaya, The Numerical Discourses of the Buddha, trans. Bhikkhu Bodi. Boston: Wisdom Press.

Brown, Clair. 2017. Buddhist Economics: An Enlightened Approach to the Dismal Science. New York: Bloomsbury.

Chakravarti, Uma. 1987. The Social Dimensions of Early Buddhism. Delhi: Oxford University Press.

Daniels, Peter. 2005. Economic Systems and the Buddhist Worldview: The 21st Century Nexus. The Journal of Socio-Economics 34 (2): 245-268.

Dhp. 2007. The Dhammapada, trans. Eknath Easwaran. Tomales, CA: Nilgiri Press.

DN. Digha Nikaya. 2012. The Long Discourses of the Buddha, trans. Maurice Walshe. Boston: Wisdom Press.

Garfield, Jay. 2001. Buddhism and Democracy. The Proceedings of the 20th World Congress of Philosophy 12: 157-172.

Ghoshal, U.N. 1959. A History of Indian Political Ideas: The Ancient Period and the Period of Transition to the Middle Ages. Oxford: Oxford University Press.

Hanh, Thich Nhat. 2006. We Have the Compassion and Understanding Necessary to Heal the World. In Mindful Politics, ed. Melvin McLeod, 129-138. Boston: Wisdom Publications.

Jayasuriya, Lakshmi. 2009. Just War Tradition and Buddhism. International Studies 46 (4): 423-438.

Jayatilleke, Kulatissa. 1967. Buddhism and International Law. The Principles of International Law in Buddhism 120: 534-563.

- 2008. Buddhism and Peace. Buddhist Publication Society. Available on line at http://bps.lk/olib/wh/wh041_Jayatillake_Buddhism-and-Peace.pdf.

Jerryson, Michael. 2013. Buddhist Traditions and Violence. In The Oxford Handbook of Religion and Violence, ed. Michael Jerryson et al., 41-66. New York: Oxford University Press.

Keown, Damien. 2000. Buddhism and Human Rights. In Contemporary Buddhist Ethics, ed. Damien Keown and Richmond Surrey, 57-79. New York: Routledge/Curzon.

King, Sallie B. 2013. War and Peace in Buddhist Philosophy. In A Companion to Buddhist Philosophy, ed. Steven M. Emmanuel, 631-650. Malden, MA: Wiley-Blackwell.

Lee, Darius. 2014. Here There Be Dragons! Buddhist Constitutionalism in the Hidden Land of Bhutan. Australian Journal of Asian Law 15 (1): 1-19.

Ling, Trevor. 1981. The Buddha's Philosophy of Man: Early Indian Buddhist Dialogues. Rutland, VT: Everyman.

Long, William. 2019. Tantric State: A Buddhist Approach to Democracy and Development in Bhutan. New York: Oxford University Press. 
Moore, Matthew. 2016. Buddhist Political Theory. New York: Oxford University Press.

Ornatowski, Gregory. 1996. Continuity and Change in the Economic Ethics of Buddhism: Evidence from the History of Buddhism in India, China, and Japan. Journal of Buddhist Ethics 3: 199-240.

Reynolds, Frank. 1993. Ethics and Wealth in Theravada Buddhism: A Study in Comparative Religious Ethics. In Ethics, Wealth, and Salvation: A Study in Buddhist Social Ethics, ed. Russell Sizemore and Donald Swearer, 59-76. Columbia, SC: South Carolina University Press.

Sizemore, Russell, and Donald Swearer. 1993. Introduction. In Ethics, Wealth, and Salvation: A Study in Buddhist Social Ethics, ed. Russell Sizemore and Donald Swearer, 1-28. Columbia: South Carolina University Press.

SN. Samyutta Nikáya. 2000. The Connected Discourses of the Buddha, trans. Bhikkhu Bodhi. Boston: Wisdom Press.

Tambiah, S.J. 1976. World Conqueror and World Renouncer. Cambridge: Cambridge University Press.

Walton, Matthew. 2012. Politics in the Moral Universe: Burmese Buddhist Political Thought. Ph.D. Dissertation, University of Washington.

Welford, Richard. 2007. Examining, Discussing, and Suggesting Possible Contributions and Role of Buddhist Economics for Corporate Social Responsibility. International Journal of Green Economics 11 (3/4): 341-350.

Open Access This chapter is licensed under the terms of the Creative Commons Attribution 4.0 International License (http://creativecommons.org/licenses/ by $/ 4.0 /)$, which permits use, sharing, adaptation, distribution and reproduction in any medium or format, as long as you give appropriate credit to the original author(s) and the source, provide a link to the Creative Commons license and indicate if changes were made.

The images or other third party material in this chapter are included in the chapter's Creative Commons license, unless indicated otherwise in a credit line to the material. If material is not included in the chapter's Creative Commons license and your intended use is not permitted by statutory regulation or exceeds the permitted use, you will need to obtain permission directly from the copyright holder.

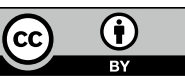

